University of Nebraska - Lincoln

DigitalCommons@University of Nebraska - Lincoln

US Army Research

U.S. Department of Defense

2013

Numerical modeling of sediment flushing from Lewis and Clark

Lake

Jungkyu Ahn

Seoul National University, ajk38317@naver.com

Chih Ted Yang

Colorado State University - Fort Collins, ctyang@engr.colostate.edu

Paul M. Boyd

U.S. Army Corps of Engineers, Paul.M.Boyd@usace.army.mil

Daniel B. Pridal

U.S. Army Corps of Engineers, daniel.b.pridal@usace.army.mil

John I. Remus

U.S. Army Corps of Engineers, John.I.Remus@usace.army.mil

Follow this and additional works at: https://digitalcommons.unl.edu/usarmyresearch

Ahn, Jungkyu; Yang, Chih Ted; Boyd, Paul M.; Pridal, Daniel B.; and Remus, John I., "Numerical modeling of sediment flushing from Lewis and Clark Lake" (2013). US Army Research. 175.

https://digitalcommons.unl.edu/usarmyresearch/175

This Article is brought to you for free and open access by the U.S. Department of Defense at DigitalCommons@University of Nebraska - Lincoln. It has been accepted for inclusion in US Army Research by an authorized administrator of DigitalCommons@University of Nebraska - Lincoln. 


\title{
Numerical modeling of sediment flushing from Lewis and Clark Lake
}

\author{
Jungkyu AHN ${ }^{1}$, Chih Ted YANG ${ }^{2}$, Paul M. BOYD ${ }^{3}$, Daniel B. PRIDAL ${ }^{4}$, and John I. REMUS ${ }^{5}$
}

\begin{abstract}
Lewis and Clark Lake is located on the main stream of the Missouri River. The reservoir is formed behind Gavins Point dam near Yankton, South Dakota, U.S.A. The Lewis and Clark Lake reach extends about $40 \mathrm{~km}$ from the Gavins Point dam. The reservoir delta has been growing since the closure of Gavins Point dam in 1955 and has resulted in a $21 \%$ reduction of storage within the maximum pool of the reservoir. Among several sediment management methods, drawdown flushing has been recommended as a possible management technique. The engineering viability of removing sediments deposited in the lake should be examined by numerical modeling before implementing a drawdown flushing. GSTARS4 was used for this study and calibrated by using measured data from 1975 to 1995 . Channel cross-section changes and amount of flushed sediment were predicted with four hypothetical flow scenarios. The flushing efficiencies of all scenarios were estimated by comparing the ratios between water consumption and flushed sediment during flushing.
\end{abstract}

Key Words: Drawdown flushing; Flushing efficiency, GSTARS computer model, Reservoir sedimentation, Sediment transport, Lewis and Clark Lake

\section{Introduction}

The Lewis and Clark Lake is located on the main stream of the Missouri River in U.S.A as shown in Fig. 1. The study reach of $110 \mathrm{~km}$ extends from Gavins Point dam to Fort Randall dam. Lewis and Clark Lake covers approximately 40 $\mathrm{km}$ at full pool. There are three main tributaries, i.e., the Niobrara River, Bazile Creek, and Ponca Creek. These three tributaries supply a large amount of sediment to the river system and form the reservoir delta which has been growing since the closure of Gavins Point dam in 1955. The braided pattern of the reservoir delta is shown in Fig. 2. As of 2007, about $21 \%$ of storage within the maximum pool of the reservoir has been lost due to sedimentation. The delta continues to expand, resulting in the loss of reservoir capacity, increased the risk of flooding, and reduction of recreational access.

Fan and Morris (1992) classified hydraulic methods to manage reservoir sediment deposition as:

1. Sediment routing during floods.

2. Drawdown flushing.

3. Emptying and flushing.

4. Venting density current.

Wang and $\mathrm{Hu}$ (2009) summarized sedimentation management strategies implemented in China and analyzed advantages and disadvantages of each method. Drawdown flushing is the most suitable for the Lewis and Clark Lake sediment management due to the very small capacity / inflow ratio, relatively deep gates, and ability to control flows from Fort Randall dam (USACE, 2002).

The Generalized Sediment Transport model for Alluvial River Simulation version 3.0 (GSTARS3) by Yang and Simões (2008) can be used to evaluate the sedimentation processes without significant water surface changes. However, GSTARS3 may not be applicable to unsteady flow conditions, because it is not a truly unsteady flow model. GSTARS4 (Yang and Ahn, 2011) was developed for the simulation of flushing studies, because it has the capability for quasisteady and truly unsteady flushing simulations.

\footnotetext{
${ }^{1}$ Research Fellow, Civil and Environmental Engineering Department, Seoul National University, Seoul, Republic of Korea, Email: ajk38317@naver.com

${ }^{2}$ Borland Professor of Water Resources and Director of Hydroscience and Training Center, Civil and Environmental Engineering Department, Colorado State University, Fort Collins, CO, USA, 80526, E-mail: ctyang@engr.colostate.edu, ctyang23@gmail.com

${ }^{3}$ Hydraulic Engineer, U.S. Army Corps of Engineers, Omaha, Nebraska, USA

${ }^{4}$ Chief, Sedimentation and Channel Stabilization Section, U.S. Army Corps of Engineers, Omaha, Nebraska, USA

${ }^{5}$ Chief, Hydrologic Engineering Branch, Omaha, Nebraska, USA

Note: The original manuscript of this paper was received in Jan.2012. The revised version was received in Feb. 2013. Discussion open until June 2014. 


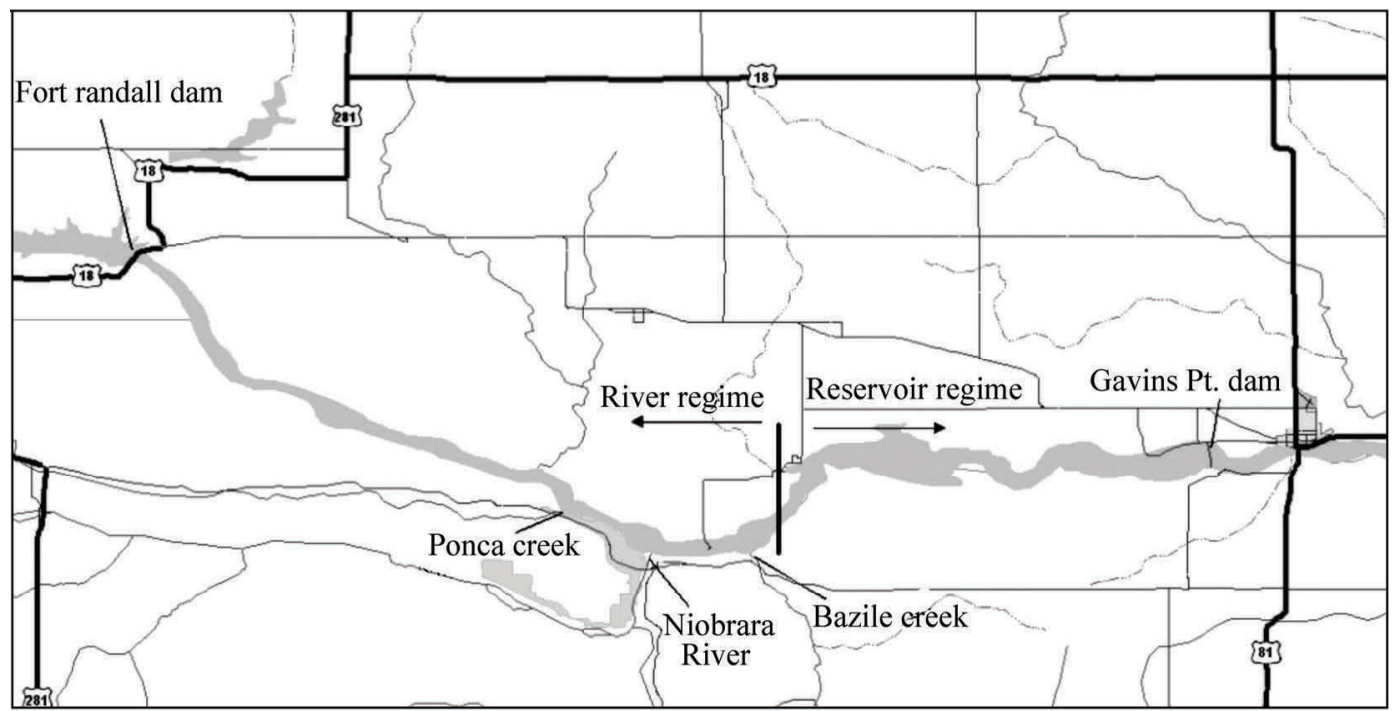

Fig. 1 Overview of Lewis and Clark Lake
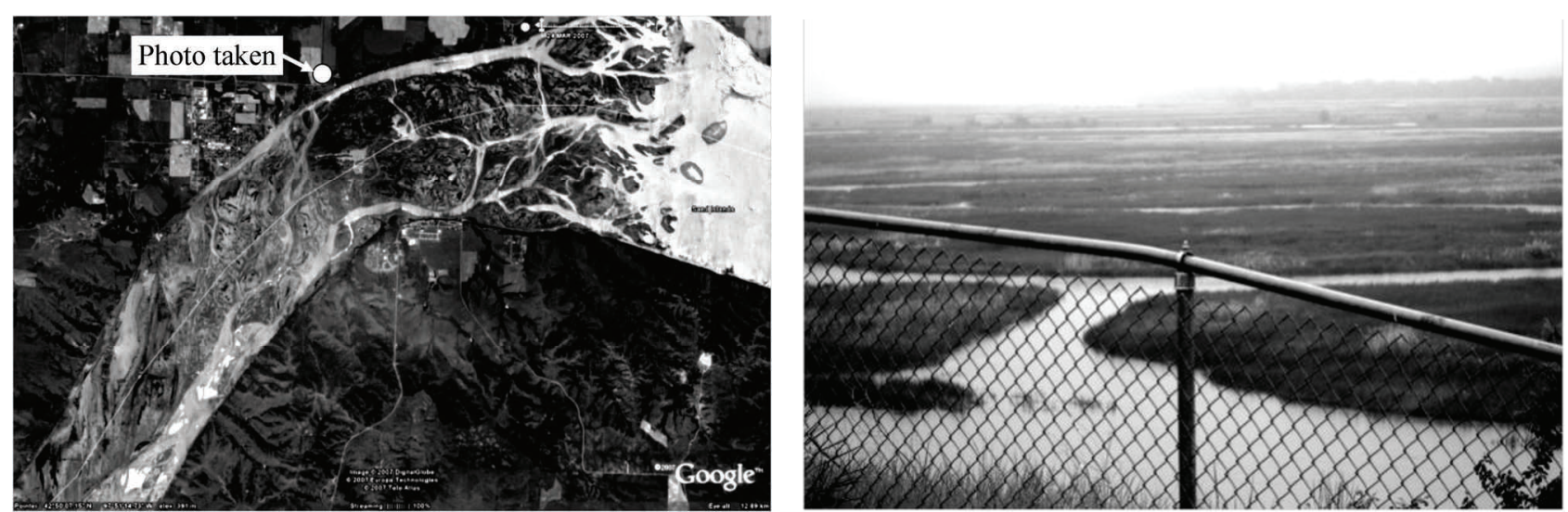

Fig. 2 Reservoir delta of Lewis and Clark Lake

Sediment transport capacity was computed by using Yang's unit stream power sediment transport formulas for sand (1973) and for gravel (1984), respectively. Yang's 1973 equation was also used for fine materials such as silt and clay in this study.

This paper summarized the simulated and predicted lake geometry changes, and the amount of sediment flushed from the reservoir with four hypothetical flushing scenarios.

\section{Calibrations using historic data}

GSTARS4 was calibrated by simulating the historic record of management of the reservoir operation from 1975 through 1995. The measured bed profile from 1975 was used as the initial boundary condition for the simulation.

Fifty-seven cross-sections surveyed in 1975, 1995 and 2007, respectively, along the $110 \mathrm{~km}$ of the study reach between Fort Randall and Gavins Point dam were available for this study.

Using measured cross-section in 1975 as the initial channel boundary, GSTARS4 was run with the hydraulic and sediment data for 20 years of record in an attempt to match the 1995 measurements. Figure 3 shows three measured thalweg bed profiles. The development of reservoir delta moves gradually toward the reservoir regime. However, scouring occurred due to the operation of Fort Randall dam in the upper river regime. At about $40-65 \mathrm{~km}$ upstream of Gavins Point dam, the thalweg bed profile changed faster than that in other parts due to sediment supply from the three tributaries, primarily from the Niobrara River.

Water discharge from Fort Randall dam and water surface elevation on Lewis and Clark Lake at Gavins Point dam were used as upstream and downstream boundary conditions, respectively. In Fig. 4, water surface elevation varies between $367 \mathrm{~m}$ and $369 \mathrm{~m}$. Although the unsteady effect may not be significant, both steady and unsteady flow routings were conducted for comparison. 


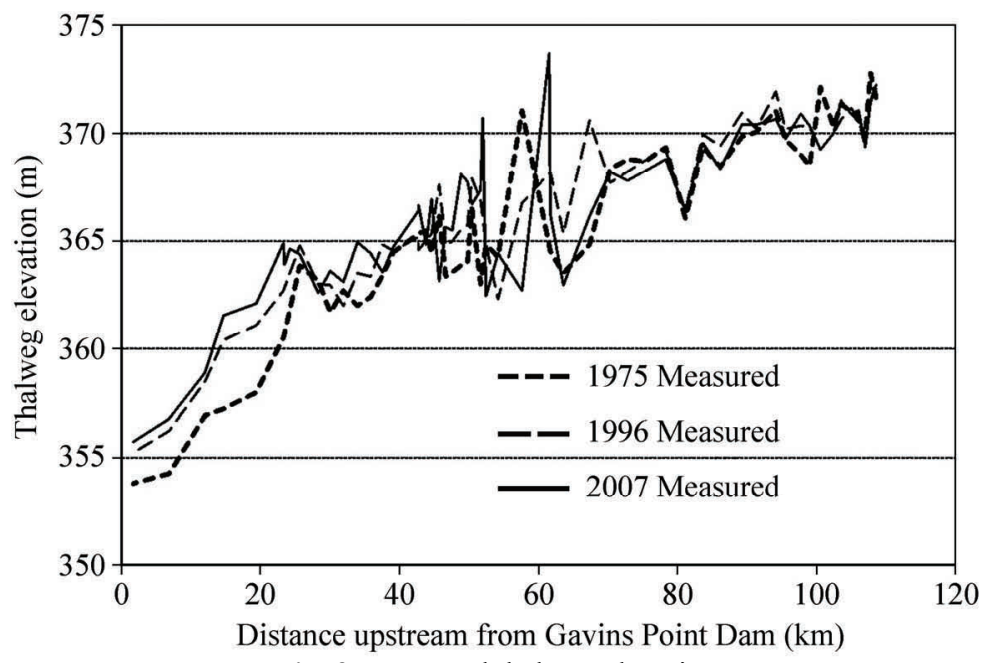

Fig. 3 Measured thalweg elevation

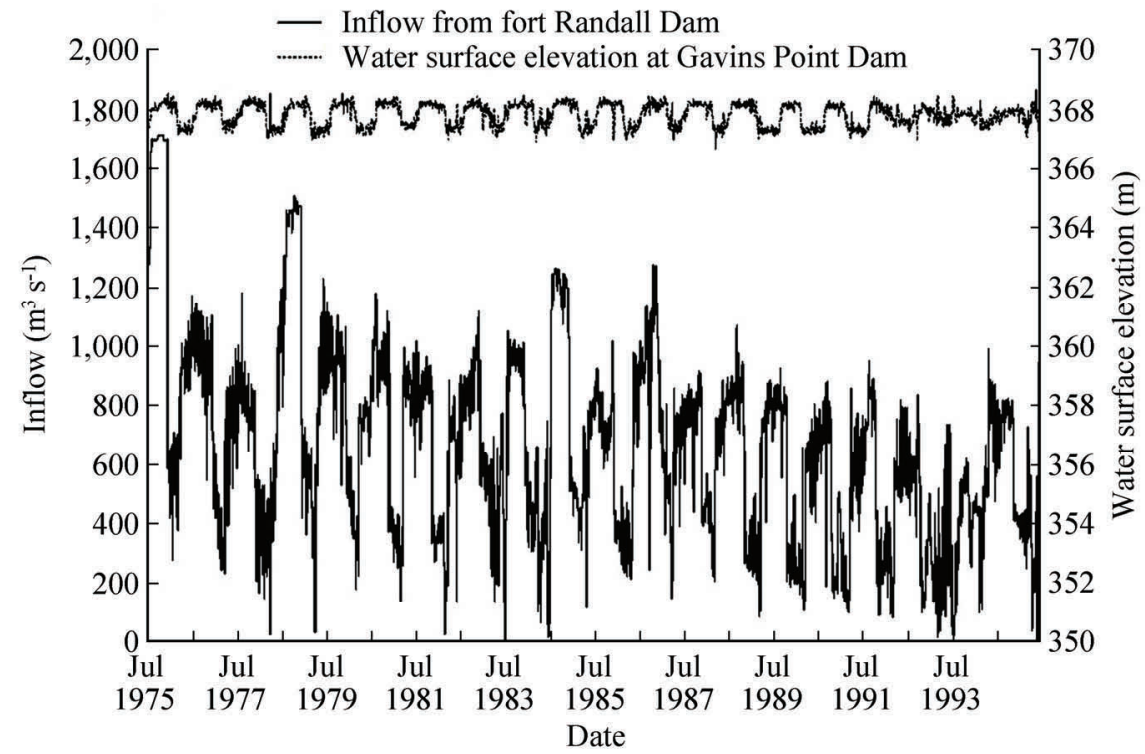

Fig. 4 Flow boundary conditions

It is assumed that sediment transport rate at the first upstream cross-section is under equilibrium condition without bed change. Sediment inflow from the upstream is calculated from Yang's 1973 sand and 1984 gravel sediment transport equations by assuming that sediment inflow is the same as the computed sediment transport capacity.

Gradation of bed material size along the study reach was surveyed in 1975 and 2007, respectively. The measured results were used for the 20-year calibration and flushing simulation, respectively. Water and sediment inflows from the three tributaries, i.e., the Niobrara River, Ponca Creek, and Bazile Creek, were considered for the modeling. Daily water discharges of the three tributaries were available. Sediment inflows from the tributaries were computed by using the following sediment rating curve of the Missouri River (USACE, 1993)

$$
Q_{s, \text { lat }}=5.45 \times 10^{-2} Q_{\text {lat }}{ }^{2.799}
$$

where $Q_{s, l a t}=$ sediment inflow from a tributary in $\mathrm{t} \mathrm{d}^{-1}$, and $Q_{\text {lat }}=$ water discharge from a tributary in $\mathrm{m}^{3} \mathrm{~s}^{-1}$.

The size distribution of sediment inflow from the three tributaries must be included in the simulation. 157 sediment samples of sediment transported in the Niobrara River were collected between 1973 and 1984. Sieve analysis was conducted for all 157 samples as shown in Fig. 5. It was assumed that three tributaries have the same size distribution as shown in Fig. 5.

Roughness coefficients were calibrated by comparing observed and computed water surface profiles. The calibration of roughness coefficient in this study focused on long term channel geometric change.

Chow (1959) recommended Manning's $n$ value of $0.025-0.100$ for natural rivers wider than $100 \mathrm{ft}$. Three values, $0.02,0.04$, and 0.06 , were tested for this study. Figure 6 shows comparisons of 20 -year profiles between the measured and simulated thalweg elevation using various Manning's $n$ values. The simulated result does not show significant 
difference with respect to various $n$ values. Table 1 shows the comparisons of the goodness-of-fit between measured and simulated thalweg elevations by the root-mean-square (RMS) calculated by

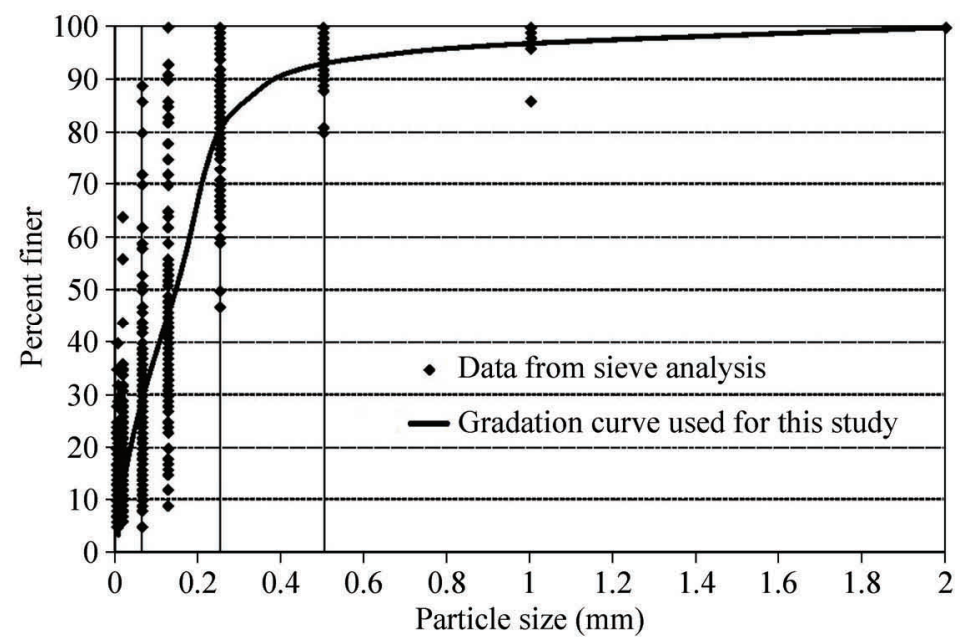

Fig. 5 Particle size distribution of sediment load assumed for all tributaries

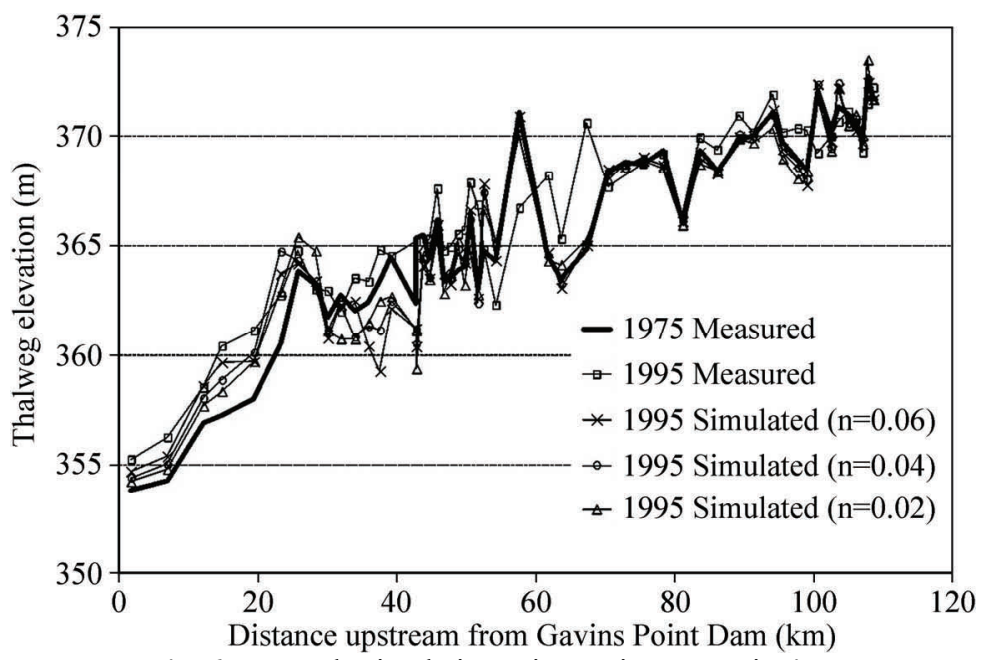

Fig. 6 Unsteady simulation using various Manning's $n$

Table 1 RMS with respect to roughness coefficient

\begin{tabular}{|c|c|}
\hline Manning's $n$ & RMS (m) \\
\hline 0.02 & 2.16 \\
\hline 0.04 & 2.08 \\
\hline 0.06 & 2.17 \\
\hline
\end{tabular}

$$
\mathrm{RMS}=\left[\sum_{i=1}^{N}\left(Z_{c i}-Z_{m i}\right)^{2} / N\right]^{1 / 2}
$$

where $Z_{c}$ and $Z_{m}=$ computed and measured thalweg elevation, respectively, $i=$ cross-section index, and $N=$ total number of cross-section.

Table 1 indicates that $n=0.04$ is the most reasonable value with the lowest RMS value. $n=0.04$ was selected for the entire reach because the thalweg bed elevation profile is not very sensitive to changing $n$ values for long term simulations.

There are delay effects for non-equilibrium sediment transport (Yang and Simões, 2002). GSTARS4 model uses the method developed by Han (1980) to simulate the delay effect.

$$
C_{i}=C_{t, i}+\left(C_{i-1}-C_{t, i-1}\right) \exp \left[-\frac{\alpha \omega \Delta x}{q}\right]+\left(C_{t, i-1}-C_{t, i}\right)\left[\frac{q}{\alpha \omega_{m} \Delta x}\right]\left[1-\exp \left(-\frac{\alpha \omega \Delta x}{q}\right)\right]
$$


where $C_{i}=$ concentration of sediment in transportation at cross section $i, C_{t, i}=$ sediment transport capacity at cross section $i$ computed from Yang (1973) for sand and Yang (1984) for gravel transport formulas, $\omega=$ fall velocity, $q=$ discharge of flow per unit width, $\Delta x=$ distance between cross section, and $\alpha=$ recovery factor.

Han and $\mathrm{He}$ (1990) recommended a $\alpha$ value of 0.25 for deposition and 1.0 for entrainment. Yang and Marsooli (2010) suggested that the recovery factor is a function of sediment size.

$$
\alpha=\frac{\varepsilon}{d^{\xi}}
$$

where $\varepsilon$, and $\xi=$ site-specific coefficients, and $d=$ sediment diameter.

The simulated long term results were not very sensitive to the variation of site-specific coefficients. For fine sediment, silt or clay, the second and third terms of the right hand side of Eq. (3) are not close to zero. For coarse sediment, sand or gravel, those two terms are close to zero. The recovery factor is sensitive to very fine materials, such as those in the Yellow River. However, recovery factor is not very sensitive for the Missouri River.

$\Delta t=1 \mathrm{hr}$ and $n=0.04$ was used for GSTARS4 for 20 years of simulation. Both quasi-steady and unsteady simulations were conducted for comparison. Figure 7 shows the comparison of thalweg profiles. Unsteady and quasi-steady simulations have nearly the same results because the unsteady effect was not significant in case of normal reservoir operation from 1975 to 1995 . However, unsteady effects are considered for drawdown flushing, which may experience faster changes in discharge and water surface elevation.

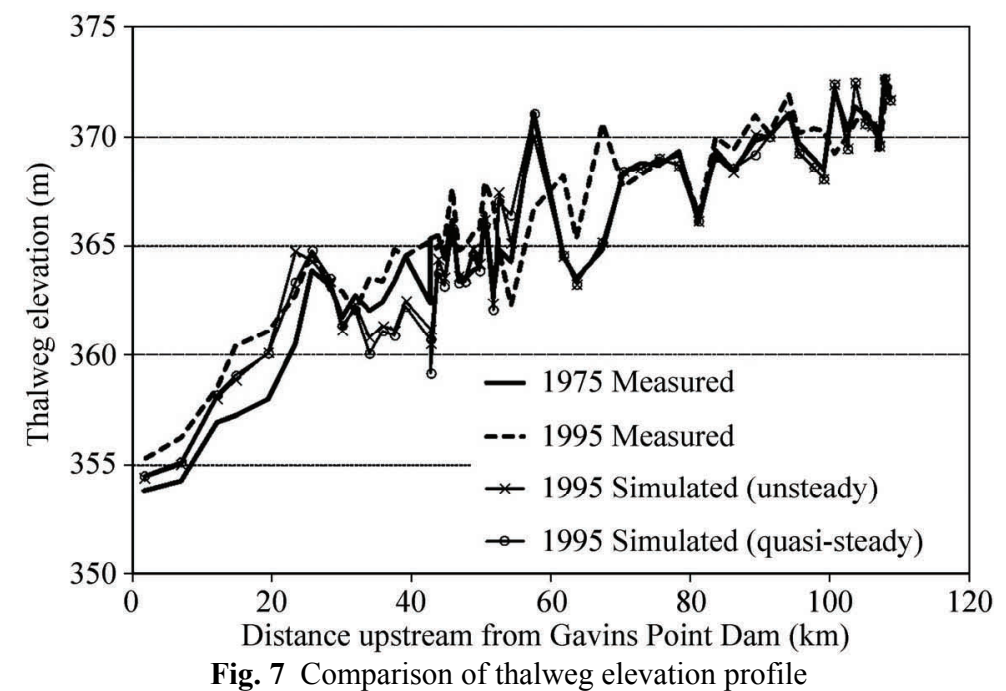

Figure 8 shows that the measured and unsteady flow simulated cross sections are close to each other except Fig. 8 (b), where the braided channels exist.

\section{Flow boundary conditions for drawdown flushing}

GSTARS4 with steady and unsteady flow simulation capabilities was tested with the field data of 1975 and 1995 . Sediment flushing efficiency was evaluated with four flow scenarios using the current 2007 survey data. The four flow scenarios are summarized in Table 2. Scenarios 1, 2, and 3 prediction of sediment flushing are based on upstream and downstream discharges of specified duration. Scenario 4 was designed to flush the mean annual sedimentation in the Lewis and Clark Lake of about $3.2 \times 10^{6} \mathrm{~m}^{3}$.

Gavins Point dam spillway has 14 bays at elevation of $359.66 \mathrm{~m}(1,180 \mathrm{ft})$ with adjustable radial sluice. Scenario 3 in Table 2 was designed to test the concept of lowering half of the gates approximately $3.0 \mathrm{~m} \mathrm{(10.0} \mathrm{ft)} \mathrm{to} \mathrm{increase} \mathrm{flushing}$ efficiency. A synthetic rating curve was developed to predict the discharge with the modified spillway.

Spillway rating curves for existing and modified spillway were used for the downstream boundary condition. The rating curve for the existing spillway is

where $H_{s}=$ water stage at the spillway in $\mathrm{m}$.

$$
H_{s}=0.0231 Q_{o}^{0.66}+359.66
$$

Similarly, the modified spillway rating curve is

$$
H_{s}=0.0532 Q_{o}^{0.5837}+356.62
$$

Equation (5) was applied for scenarios 1, 2, and 4 and Eq. (6) was used for scenario 3. 

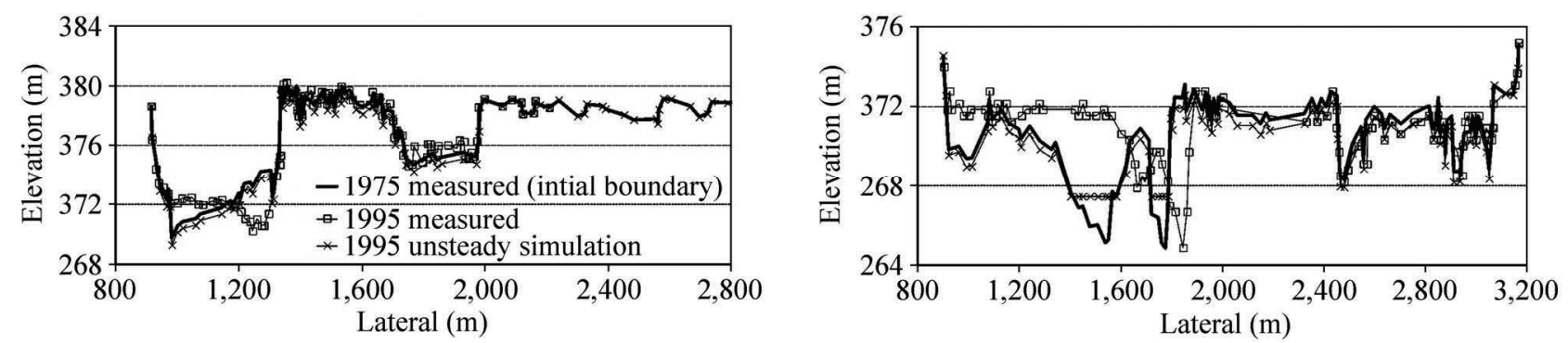

(a) $95.5 \mathrm{~km}$ upstream of Gavins Point dam

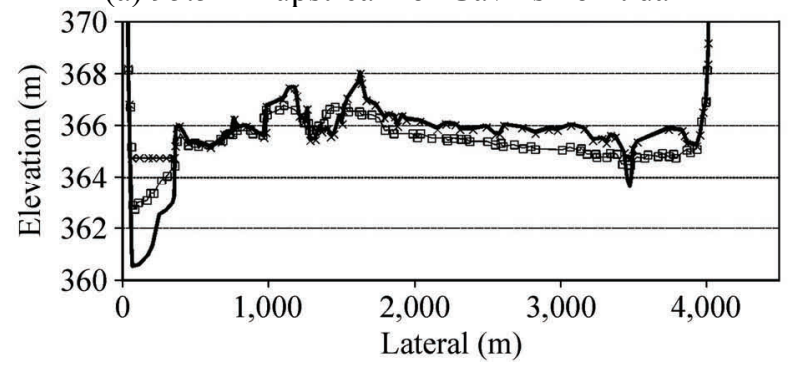

(c) $23.2 \mathrm{~km}$

(b) $52.5 \mathrm{~km}$

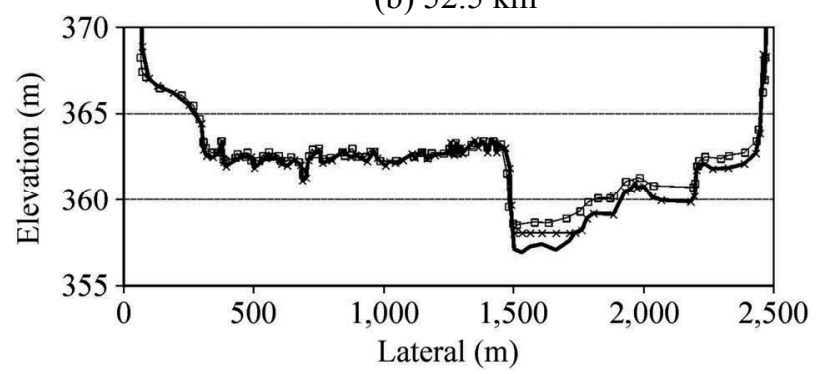

(d) $12.1 \mathrm{~km}$

Fig. 8 Comparison between measured and unsteady simulated cross sections

Table 2 Description of four flow scenarios

\begin{tabular}{|c|c|c|c|c|c|c|c|c|}
\hline \multirow{2}{*}{$\begin{array}{c}\text { Scenario } \\
\text { no. }\end{array}$} & \multirow{2}{*}{$\begin{array}{c}\text { Gavins Point } \\
\text { dam spillway }\end{array}$} & \multirow{2}{*}{$\begin{array}{c}\text { Days of main } \\
\text { flushing }\end{array}$} & \multicolumn{6}{|c|}{ Discharge $\left(\mathrm{m}^{3} \mathrm{~s}^{-1}\right)$} \\
\cline { 3 - 8 } & & & \multicolumn{2}{|c|}{ For initial lake drain* } & \multicolumn{2}{|c|}{ For main flushing* } & \multicolumn{2}{c|}{ For reservoir refilling* } \\
\cline { 3 - 8 }${ }^{* * *}$ & $Q_{i}^{* *}$ & $Q_{o}{ }^{*}$ & $Q_{i}$ & $Q_{o}$ & $Q_{i}$ & $Q_{o}$ \\
\hline 1 & Existing & 8 & 1,557 & 2,265 & 4,842 & 4,984 & 2,124 & 1,699 \\
\hline 2 & Existing & 10 & 425 & 1,133 & 2,350 & 2,492 & 991 & 566 \\
\hline 3 & Modified & 8 & 1,557 & 2,265 & 4,842 & 4,984 & 2,124 & 1,699 \\
\hline 4 & Existing & $\begin{array}{c}\text { Until } 3.2 \times 10^{6} \mathrm{~m}^{3} \text { of } \\
\text { sediment flushed }\end{array}$ & 425 & 1,133 & 2,350 & 2,492 & 991 & 566 \\
\hline
\end{tabular}

* In all cases, combined tributary inflow from three tributaries is $142 \mathrm{~m}^{3} \mathrm{~s}^{-1}\left(=5,000 \mathrm{ft}^{3} \mathrm{~s}^{-1}\right)$ through out the entire operation. Total inflow for each scenario is the upstream discharge plus tributary inflow.

** $Q_{i}=$ discharge from the upstream boundary.

** $Q_{o}=$ discharge at the downstream boundary, spillway at Gavins Point dam.

Each drawdown flushing operation consists of three stages: initial draining of the lake, main flushing, and reservoir refilling. The reservoir was drained first to increase flushing efficiency by lowering lake water surface elevation. The lake would be restored at the end of flushing operation. The initial water stage at the spillway was assumed at $368.20 \mathrm{~m}$ for all scenarios.

Timing and duration of the flushing peak must be matched with the initial draining and refilling to prevent extreme changes in lake stage. When draining the lake, gates must be opened gradually to prevent a short duration extreme flood below the dam. During refilling, the gates must be closed at a rate not to cause overtopping.

The detailed flow hydrograph for flow scenario 1 is shown in Fig. 9 (a) and Table 3.

The initial draining of the lake will be conducted from 0 to 7 days. The discharge at both the upstream and downstream were used as boundary conditions for the initial draining. At day 7, water surface elevation at Gavins Point dam is approximately $362.71 \mathrm{~m}$.

After the initial lake draining, Gavins Point dam spillway gates will be fully open. The rating curve for the existing spillway, Eq. (5), was used as the downstream boundary condition. The incoming discharge controlled by the operation of Fort Randall dam is shown in Fig. 9 (a) and Table 3 (a). Flushing discharge of $4,842 \mathrm{~m}^{3} \mathrm{~s}^{-1}$ was maintained for 8 days during the main flushing.

After the main flushing, upstream discharge at Fort Randall dam will be decreased gradually until the upstream discharge reaches $2,124 \mathrm{~m}^{3} \mathrm{~s}^{-1}$ from day 16 to 17 . After the main flushing, the upstream discharge will be reduced first and spillway gates at Gavins Point dam will be closed later. The downstream discharge reduction will lag the reduction at Fort Randall dam to prevent exceeding the maximum pool of Lewis and Clark Lake.

Upstream and downstream discharges were maintained at 2,124 and 1,699 $\mathrm{m}^{3} \mathrm{~s}^{-1}$, respectively for refilling. Flushing scenario 1 was completed in 25 days. The water surface elevation at Gavins Point dam was then returned to the initial stage.

Flow boundary conditions of flow scenarios 2 and 3 are similar to that of scenario 1. Figures 9 (b) and (c) show discharges and operations at both upstream and downstream boundaries for scenario 2 and 3 .

International Journal of Sediment Research, Vol. 28, No. 2, 2013, pp. 182-193

$-187-$ 
Flow scenario 4 has eight days of operation to flush approximately the mean annual sedimentation volume of $3.2 \times 10^{6}$ $\mathrm{m}^{3}$. Eight days of operation was determined by trial-and-error. The initial draining of the lake lasts only 6 hours and both upstream and downstream discharges should be increased. The duration of the main flushing is very short and reservoir refilling follows. Detailed operation of scenario 4 is shown in Fig. 9 (d).

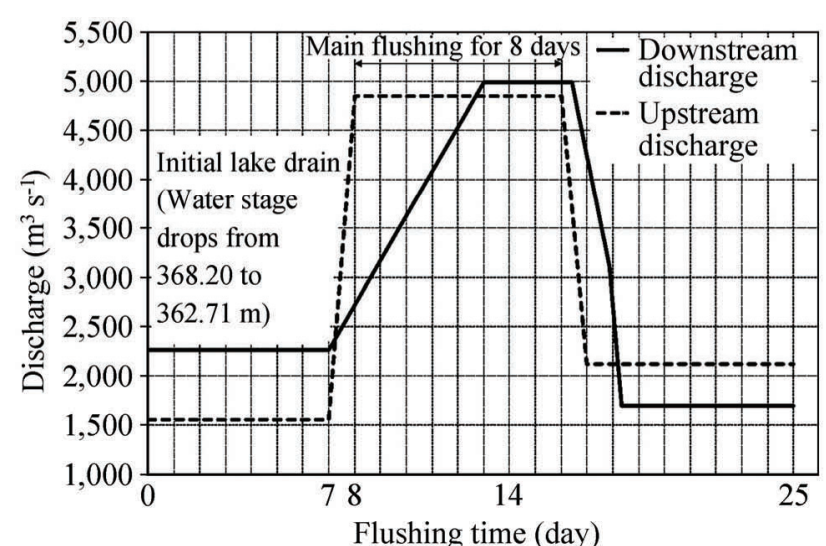

(a) Scenario 1

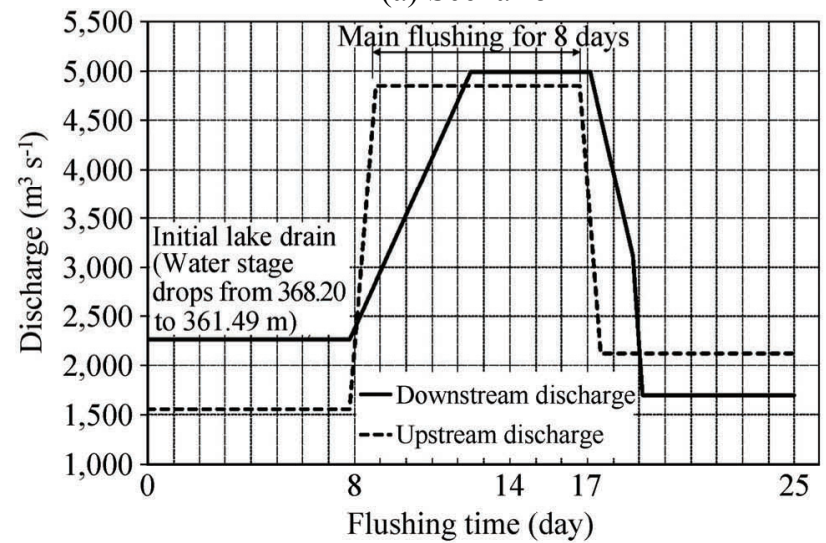

(c) Scenario 3

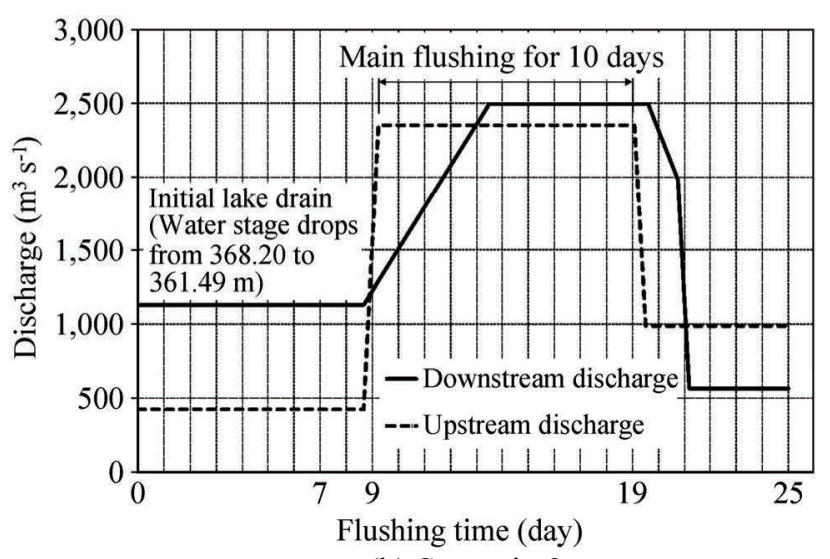

(b) Scenario 2

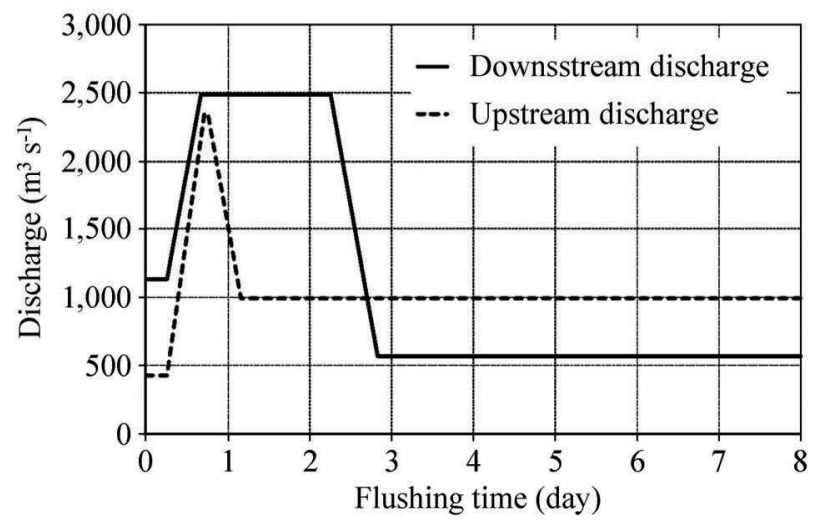

(d) Scenario 4

Fig. 9 Upstream and downstream discharges for flow scenarios

Table 3(a) Upstream discharge of flow scenario 1

\begin{tabular}{|c|c|l|}
\hline Operation time in days & Discharge $\left(\mathrm{m}^{3} \mathrm{~s}^{-1}\right)$ & \multicolumn{1}{c|}{ Remarks } \\
\hline 0 & 1,557 & Beginning of scenario 1 \\
\hline $0-7(168 \mathrm{hr})$ & 1,557 & Maintain discharge \\
\hline $7(168 \mathrm{hr})-8(192 \mathrm{hr})$ & $1,557 \sim 4,842$ & Start increasing discharge by $141.58 \mathrm{~m}^{3} \mathrm{~s}^{-1}$ per hour \\
\hline $8(192 \mathrm{hr})-15.8(380 \mathrm{hr})$ & 4,842 & Maintain discharge \\
\hline $15.8(380 \mathrm{hr})-16.7(400 \mathrm{hr})$ & $4,842 \sim 2,124$ & Start decreasing discharge by $141.58 \mathrm{~m}^{3} \mathrm{~s}^{-1}$ per hour \\
\hline $16.7(380 \mathrm{hr})-25(600 \mathrm{hr})$ & 2,124 & Reservoir refilling \\
\hline
\end{tabular}

Table 3(b) Operation of the downstream spillway for flow scenario 1

\begin{tabular}{|c|c|c|c|}
\hline Operation time in days & Spillway operation & Discharge $\left(\mathrm{m}^{3} \mathrm{~s}^{-1}\right)$ & Remarks \\
\hline 0 & & 2,265 & Beginning of scenario 1 \\
\hline $0-7(168 \mathrm{hr})$ & Maintain $2,265 \mathrm{~m}^{3} \mathrm{~s}^{-1}$ of discharge & 2,265 & 2,265 \\
\hline $7(168 \mathrm{hr})$ & Open spillway gates fully & $2265-4984$ & $\begin{array}{c}\text { Discharge increases and } \\
\text { decreases gradually }\end{array}$ \\
\hline $7(168 \mathrm{hr})-17.9(429 \mathrm{hr})$ & Let the water flow through spillway & $3,115-1,699$ & $\begin{array}{c}\text { Reduce discharge from } \\
3,115 \mathrm{~m}^{3} \mathrm{~s}^{-1} \text { by } 141.58 \mathrm{~m}^{3} \mathrm{~s}^{-1} \text { per hour }\end{array}$ \\
\hline $17.9(429 \mathrm{hr})-18.3(440 \mathrm{hr})$ & Start closing spillway gates & 1,699 & Reservoir refilling \\
\hline $18.3(440 \mathrm{hr})-25(600 \mathrm{hr})$ & Maintain $1,699 \mathrm{~m}^{3} \mathrm{~s}^{-1}$ of discharge & \multicolumn{2}{|c}{} \\
\hline
\end{tabular}

The stability criteria for steady simulation (Yang and Simões, 2002) is

$$
\left|c_{k}\right| \frac{\Delta t}{\Delta x} \leq 1
$$

where $c_{k}=$ kinematic wave speed of the bed change, $\Delta t=$ time step, and $\Delta x=$ distance used in the computation.

$-188-$

International Journal of Sediment Research, Vol. 28, No. 2, 2013, pp. 182-193 
The stability criteria for unsteady flow by Ahn (2011) and Yang and Ahn (2011) is

$$
\left|c_{e u}\right| \frac{\Delta t}{\Delta x} \leq 1
$$

where

$$
\left|c_{e u}\right|=-\frac{b v C_{v}}{\eta} \frac{(\beta-1)}{1-(\beta-1)^{2} F r^{2}}
$$

where $b=$ a site specific constant, $v=$ flow velocity, $C_{v}=$ sediment concentration, $\eta=$ volume of sediment in a unit bed layer volume (one minus porosity), $\beta=5 / 3$ when the Manning's equation is used, and $F r=$ Froude number

\section{Prediction of flushing efficiency}

GSTARS4 has the capability of simulating the channel geometry changes in a semi-two dimensional manner by using stream tube concept (Yang and Ahn, 2011). Three stream tubes were used to consider lateral variation of scour and deposition in the channel. Unsteady flow simulations were conducted with four flushing scenarios.

Scenarios 1 and 3 have almost the same operation, such as the same water discharge for the main flushing, initial lake drain, and refilling. The difference between the two scenarios is that the existing spillway is used for scenario 1 and the modified spillway used in scenario 3. When the spillway gates are fully open, Eqs. (5) and (6) should be used for the existing and modified spillway, respectively. Enhancement of flushing efficiency by spillway modification was evaluated by comparing the results of the two scenarios. Scenario 3 has more scour between $0-30 \mathrm{~km}$ upstream the Gavins Point dam as shown in Figs. 10 and 11. Scenarios 1 and 3 have almost identical bed profile for the initial drain. However, scenarios 3 has more scour during the main flushing. More sediment can be flushed out with scenario 3 than that of scenario 1, as shown in Fig. 12, because the modified spillway has lower water surface elevation than the existing one.

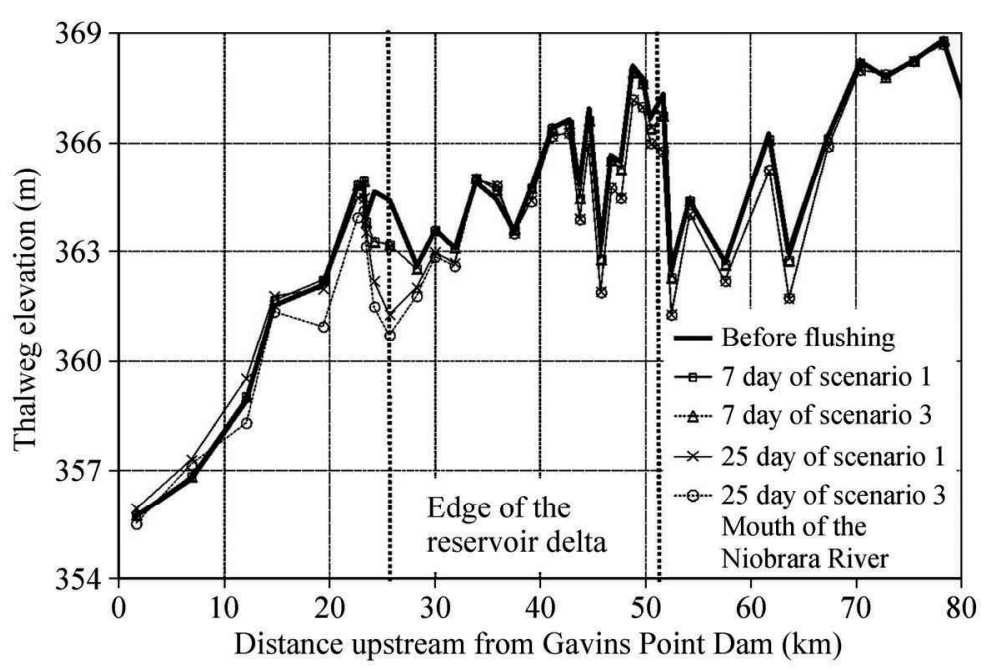

Fig. 10 Bed elevations of scenario 1 and 3

Comparison between flushing discharges were made between scenario 1 and 2. Scenario 1 has slightly more sediment flushing than scenario 2 with more scour between the edge of the reservoir delta and the mouth of the Niobrara River as shown in Fig. 13, Figs. 14 (a), and (b). Total amount of flushed sediment and water surface change of scenarios 1 and 2 are shown in Fig. 15. Scenario 1 has more sediment flushing throughout entire operation. Both scenarios ended with water surface elevation of $367 \mathrm{~m} \sim 368 \mathrm{~m}$, which is close to the initial water stage at the spillway.

Scenario 4 was designed to flush mean annual sedimentation of $3.2 \times 10^{6} \mathrm{~m}^{3}$ in the Lewis and Clark Lake. Fig. 16 shows some scour around the edge of the reservoir delta. Figure 17 shows that water surface dropped for the main flushing and recovered at the end of operation. The main flushing of scenario 4 should be started without full water surface drop to limit the flushed sediments to the annual sedimentation volume. The main flushing started when the water surface elevation at the downstream boundary was about $366 \mathrm{~m}$, as shown in Fig. 17. Other scenarios with full water surface drawdown have lower than $366 \mathrm{~m}$ at the initial drain.

Total amount of flushed water and sediment for all four scenarios are summarized in Table $4.416 \mathrm{~kg} \mathrm{~m}^{-3}$ for clay, $1,120 \mathrm{~kg} \mathrm{~m}^{-3}$ for silt, and $1,550 \mathrm{~kg} \mathrm{~m}^{-3}$ for sand were used to convert sediment from weight to volume (Yang, 1996 and 2003). Flushing efficiency was evaluated by considering flushed water / sediment ratio. 


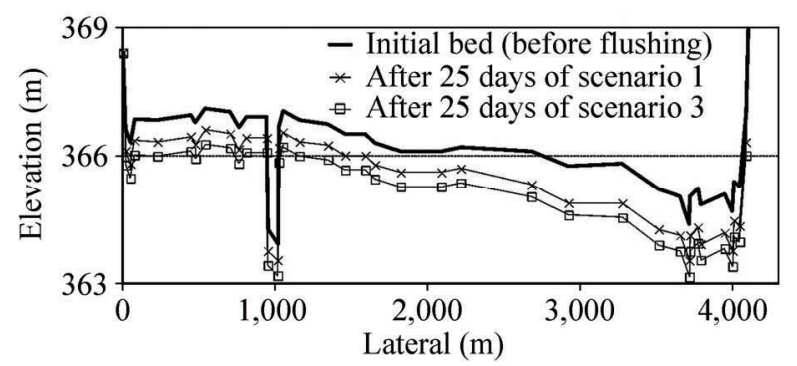

(a) At $23.4 \mathrm{~km}$ from Gavins point dam

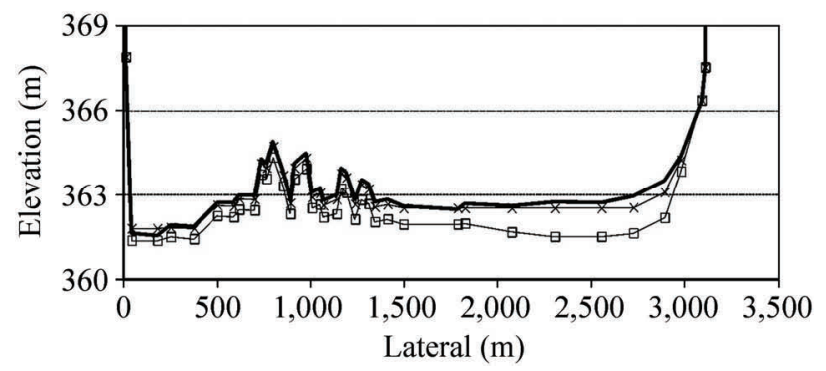

(c) $14.7 \mathrm{~km}$

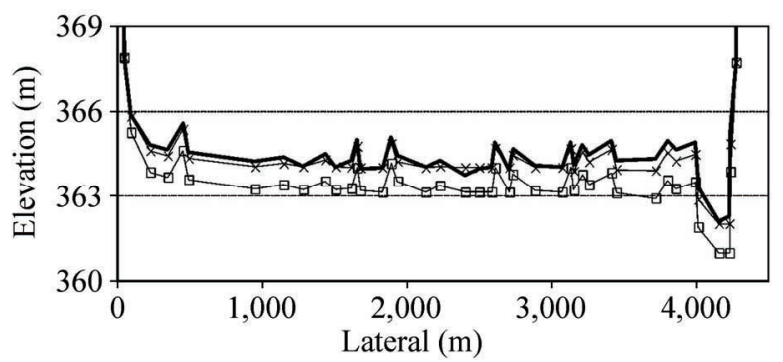

(b) $19.4 \mathrm{~km}$

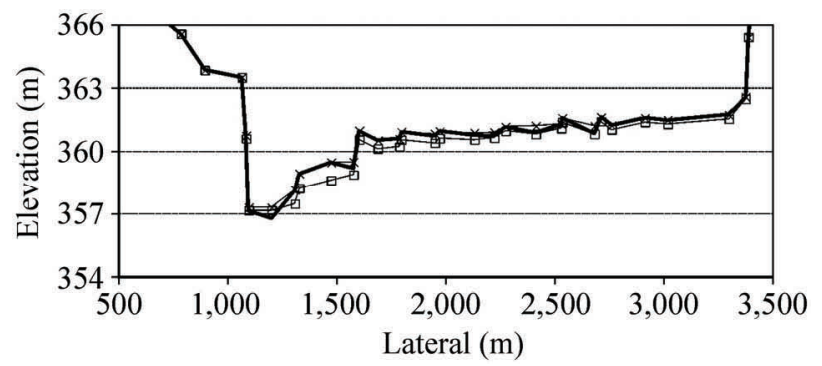

(d) $6.9 \mathrm{~km}$

Fig. 11 Cross section changes of scenarios 1 and 3

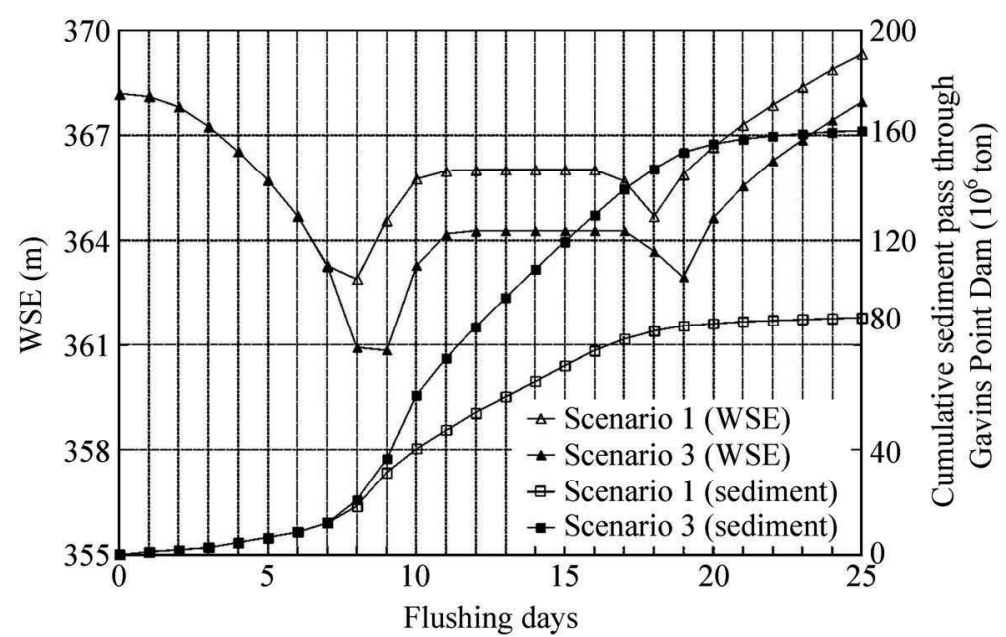

Fig. 12 Water surface elevation at Gavins Point dam spillway and cumulative flushed sediment of scenario 1 and 3

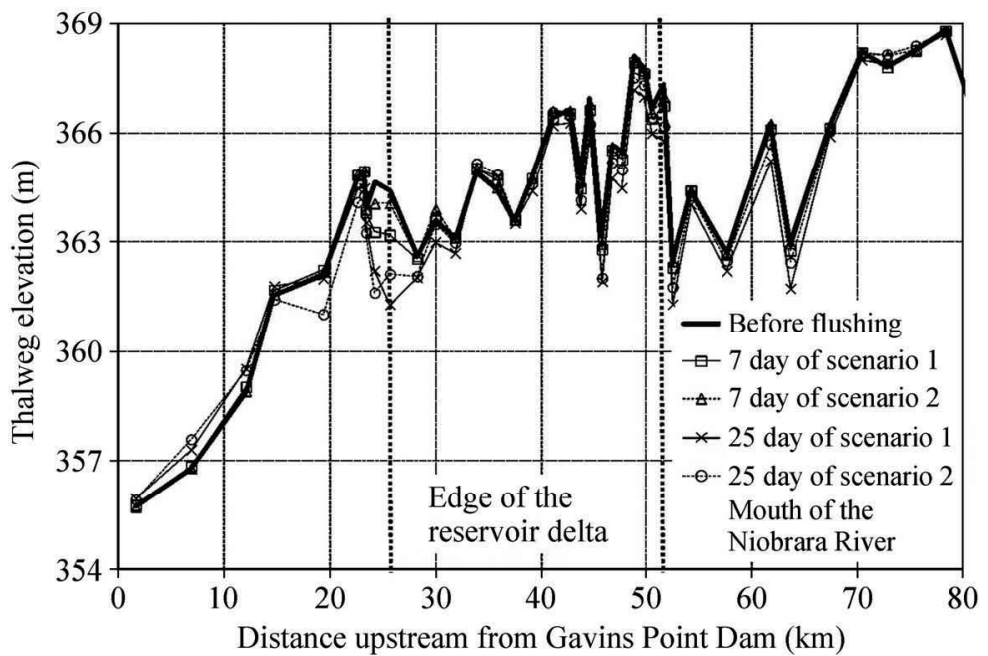

Fig. 13 Bed elevations of scenario 1 and 2 


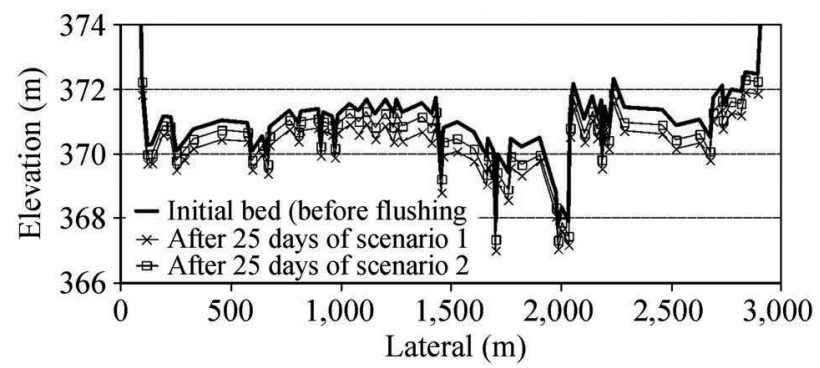

(a) At $49.7 \mathrm{~km}$ from Gavins Point dam

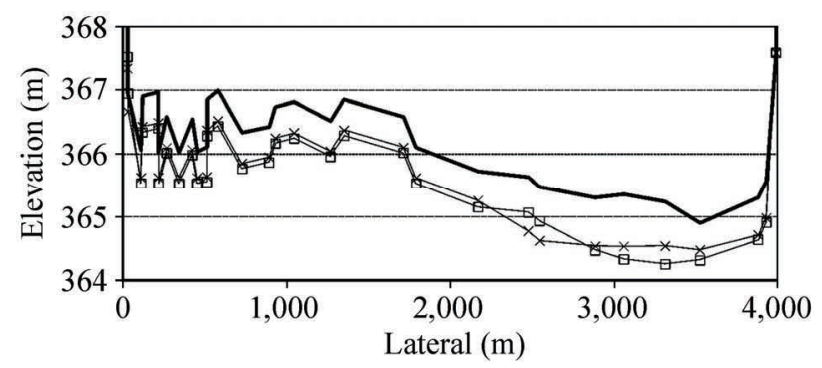

(c) $21.6 \mathrm{~km}$

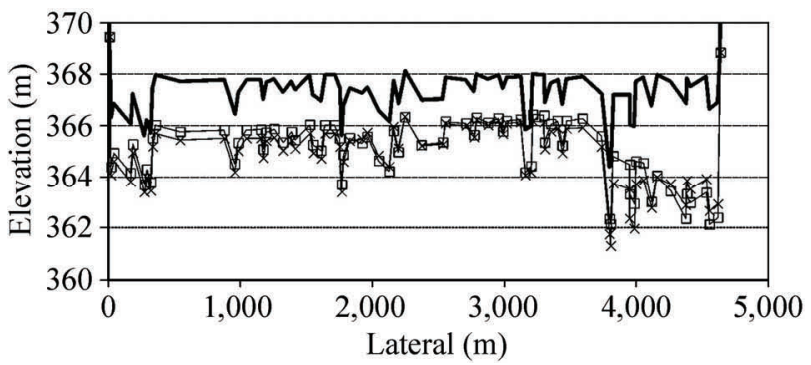

(b) $24.1 \mathrm{~km}$

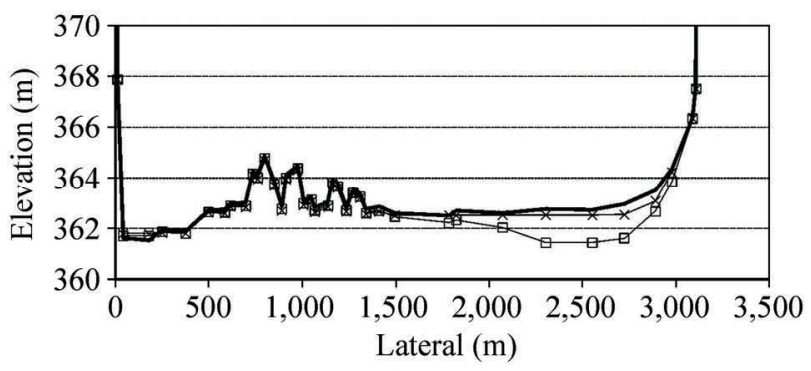

(d) $13.1 \mathrm{~km}$

Fig. 14 Cross section changes of scenarios 1 and 2

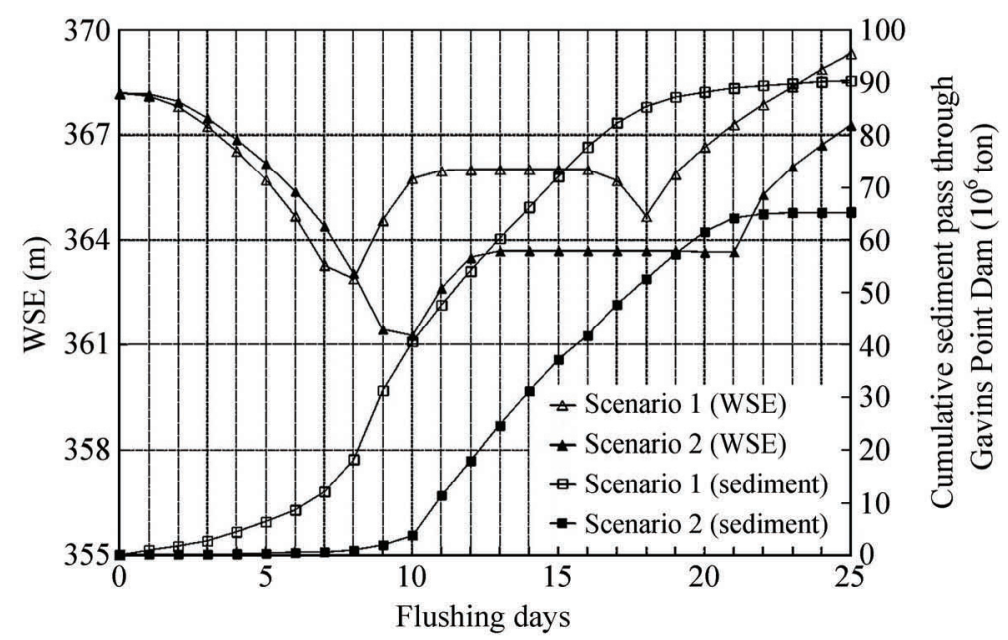

Fig. 15 Water surface elevation at Gavins Point dam spillway and cumulative flushed sediment of scenario 1 and 2

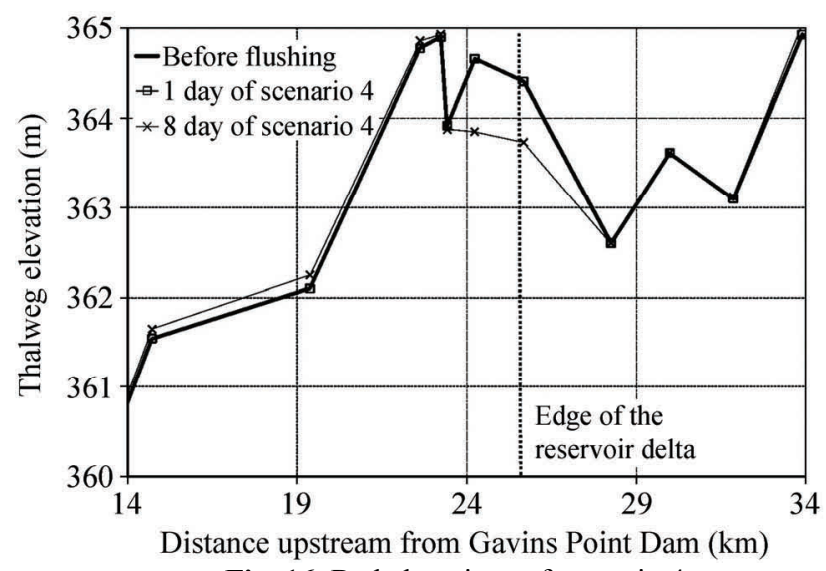

Fig. 16 Bed elevations of scenario 4

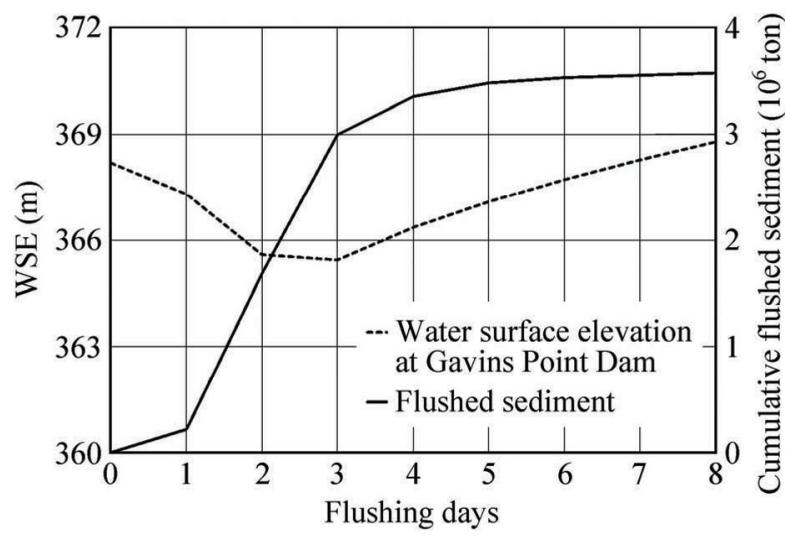

Fig. 17 Water surface elevation at Gavins Point dam spillway and cumulative flushed sediment of scenario 4 
Table 4 Summary of amount of water and sediment discharged through the Gavins Point dam spillway

\begin{tabular}{|c|c|c|c|c|c|}
\hline \multirow{2}{*}{ Scenario no. } & \multirow{2}{*}{$\begin{array}{c}\text { Total operation } \\
\text { days }\end{array}$} & \multirow{2}{*}{$\begin{array}{c}\text { Cumulative water } \\
\text { past Gavins Point } \\
\text { dam }\left(10^{8} \mathrm{~m}^{3}\right)\end{array}$} & \multicolumn{2}{|c|}{$\begin{array}{c}\text { Cumulative sediment transport } \\
\text { past Gavins Point dam }\end{array}$} & \multirow{2}{*}{$\begin{array}{c}\text { Ratio of discharged } \\
\text { water / sediment }\end{array}$} \\
\cline { 4 - 5 } & & 64.8 & 90.4 & 117.7 & 55.1 \\
\hline 1 & 25 & 32.8 & 65.3 & 84.9 & 38.7 \\
\hline 2 & 25 & 65.1 & 161.8 & 210.4 & 30.9 \\
\hline 3 & 25 & 7.6 & 3.5 & 4.7 & 163.1 \\
\hline
\end{tabular}

Scenario 3 required the least water consumption of $30.9 \mathrm{~m}^{3}$ of water to flush $1 \mathrm{~m}^{3}$ of sediment. Without considering the modification of spillway, scenario 2 was most effective. Between scenarios 1 and 2, water consumption decreased by $49 \%$ while total sediment flushing decreased by only $28 \%$.

Figure 18 shows simulated mass balance plots of all scenarios. Most scour occurred between the downstream edge of the reservoir delta and the mouth of the Niobrara River, where the majority of sediments have deposited. There were some depositions below the reservoir delta for all scenarios. It was found that there was less sediment deposition in the lake with the modified spillway by comparing Fig. 18 (a) and (c). Modification of the spillway reduces the water surface elevation in the main flushing operation by approximately $2 \mathrm{~m}$, as shown in Fig. 12, resulting in more sediment transport through the Gavins Point dam spillway.

\section{Summary and conclusions}

GSTARS4 was applied to Lewis and Clark Lake sedimentation and flushing studies. The model calibration of Manning's $n$ was conducted with simulations using historic data from 1975 to 1995. Simulated results with quasi-steady and unsteady flows are similar and it was concluded that unsteady effect is not significant for the common reservoir operation. Stability criteria for steady and unsteady flow simulations are given in this paper.

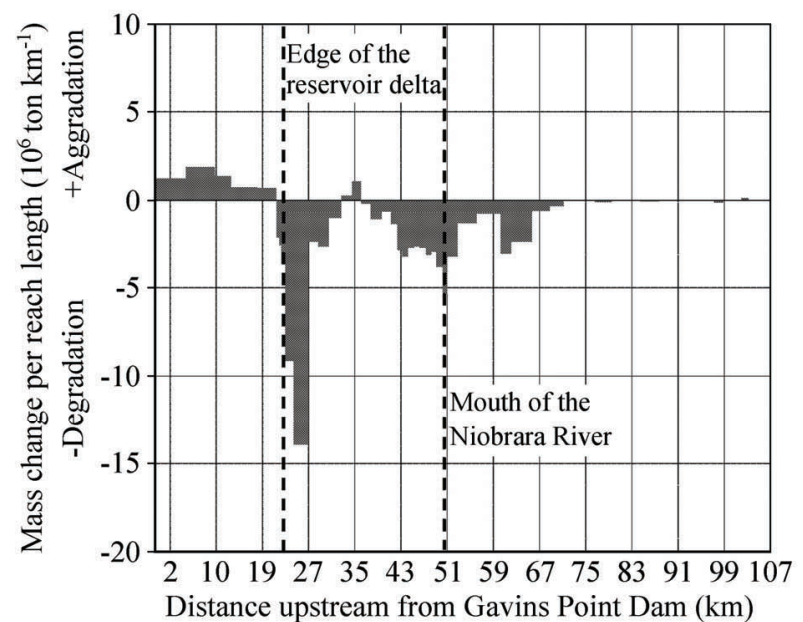

(a) Scenario 1

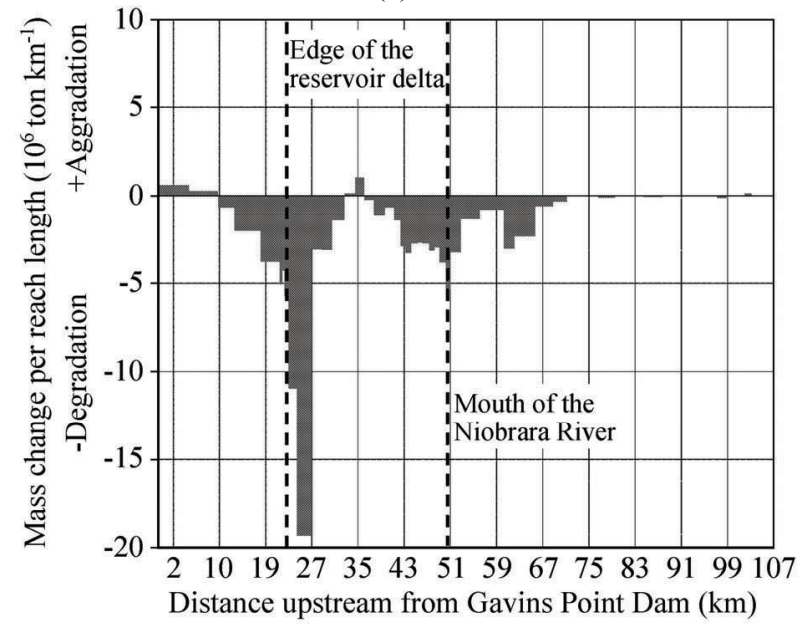

(c) Scenario 3

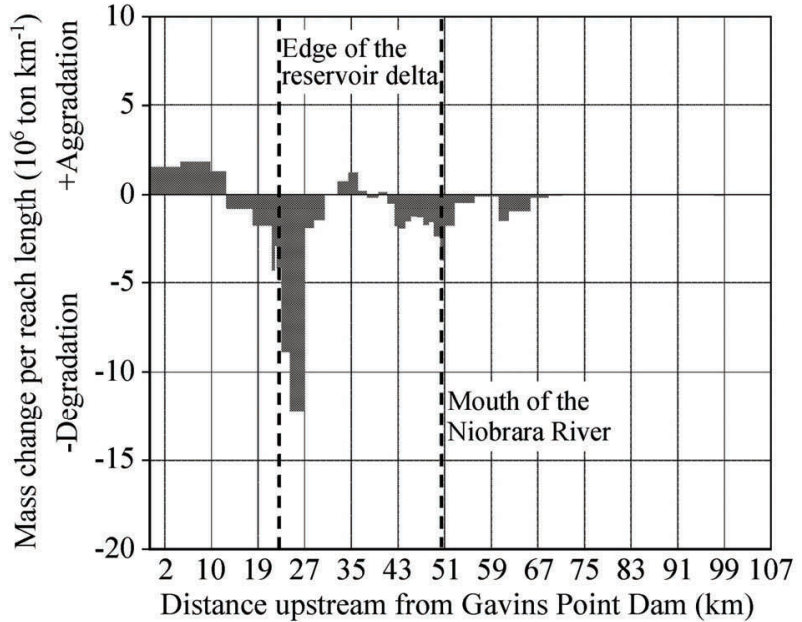

(b) Scenario 2

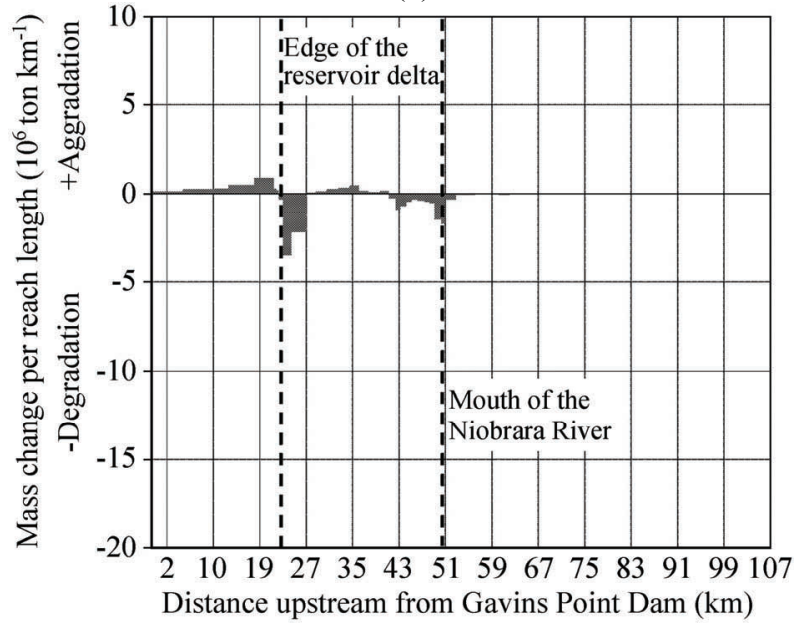

(d) Scenario 4 
The efficiency of flushing operation in Lewis and Clark Lake was predicted with four flow scenarios by comparing flushed water / sediment ratio computed from unsteady simulation. The modification of spillway, lowering half of the spillway gates by $3 \mathrm{~m}$, flushes more sediment by lowering water surface elevation during the main flushing. Comparison between scenarios with and without the modification of spillway concluded that spillway with lowered crest increases sediment flushing efficiency. Increasing the main flushing discharge flushes more sediment but appears to reduce sediment flushing efficiency.

The GSTARS4 simulations predicted that most scour will occur on the reservoir delta. Some scour sediment will not be flushed through the spillway but will deposit in the open reservoir as a part of flushing process. There would be less remaining sediment with lower spillway crest.

Sedimentation is dominant for the normal reservoir operation while erosion is dominant for a flushing operation. However, there was some scour in the upstream reach, just downstream of Fort Randall dam, during 20 years of simulation. During flushing operations scour of sediment occurs where sedimentation was dominant during the 20 years of simulation. Deposition occurs just upstream of Gavins Point dam as expected. The numerical model was applied for the $110 \mathrm{~km}$ long reach where both scour and deposition coexist regardless of reservoir operation scheme. The simulated and predicted results are reasonable based on the U.S. Army Corps of Engineers experiences and records. The results learned from this study may be applicable to other reservoirs for flushing sedimentation.

\section{References}

Ahn J. 2011, Numerical Modeling of Reservoir Sedimentation and Flushing Processes, Ph.D. Dissertation, Department of Civil and Environmental Engineering, Colorado State University, Fort Collins, Colorado.

Chow V. T. 1959, Open-Channel Hydraulics. McGraw-Hill Book Co., New York.

Fan J. and Morris G. L. 1992, Reservoir Sedimentation. I: Delta and Density Current Deposits. Journal of Hydraulic Engineering, ASCE, Vol. 118, No. 3, pp. 354-369.

Han Q. W. 1980, A study on the non-equilibrium transportation of suspended load, Proc., the First International Symposium on River Sedimentation, Beijing, China, pp. 793-802. (in Chinese.).

Han, Q. W. 2003, Reservoir Sedimentation. Science Publication, Beijing (in Chinese).

Simões F. J. M. and Yang C. T. 2008, GSTARS computer models and their applications, Part II: Applications. International Journal of Sediment Research, Vol. 23, No. 4, pp. 299-315.

U.S. Army Corps of Engineers, Omaha District, 1993, Niobrara River Sedimentation impact study phase II. Omaha, Nebraska, USA.

U.S. Army Corps of Engineers, Omaha District, 2002, Conceptual analysis of sedimentation issues on the Niobrara and Missouri Rivers, South Dakota and Nebraska. Omaha, Nebraska, USA.

Wang Z. and Hu C. 2009, Strategies for managing reservoir sedimentation. International Journal of Sediment Research, Vol. 24, No. 4, pp. 369-384.

Yang C. T. 1973, Incipient motion and sediment transport. Journal of Hydraulics Division, ASCE, Vol. 99, No. HY10, pp. 16791704.

Yang C. T. 1984, Unit stream power equation for gravel. Journal of Hydraulic Engineering, ASCE, Vol. 110, No. HY12, pp. 17831797.

Yang C.T. 1996, Sediment transport: theory and practice. McGraw-Hill Companies, Inc., New York (reprint by Krieger Publishing Company, 2003).

Yang C. T. and Ahn J. 2011, User's manual for GSTARS4 (Generalized Sediment Transport model for Alluvial River Simulation version 4.0). Hydroscience and Training Center, Colorado State University, Fort Collins, Colorado, USA.

Yang C. T. and Marsooli R. 2010, Recovery factor for non-equilibrium sedimentation processes. Journal of Hydraulic Research, Vol. 48, No. 3, pp. 409-413.

Yang C. T. and Simões F. J. M. 2002, User's manual for GSTARS3 (Generalized Sediment Transport model for Alluvial River Simulation version 3.0). Technical Service Center, U.S. Bureau of Reclamation, Denver, Colorado, USA. 